\title{
VISUAL JOURNALISM AND ITS GENRES \\ IN THE BRITISH PRESS COVERAGE OF THE "REFUGEE CRISIS" \\ (ON MATERIALS OF THE GUARDIAN)
}

\section{Alla Kovalenko,}

$\mathrm{PhD}$ (Philology), Associate Professor of the Periodical Press and Media

Editing Chair Odesa I. I. Mechnikov National University

e-mail: longms@rambler.ru

\section{Natalia Alekseeva,}

Postgraduate Student of the English Grammar Chair

Odesa I. I. Mechnikov National University

e-mail: natalie.m.alekseeva@gmail.com

In the process of investigating the case and studying media coverage of the social problem of the "refugee crisis" in European countries, monitoring of journalistic materials and sessions of photos in the newspaper "The Guardian" was carried out. The influence of visual components on the perception of the readership in the covering of the above-mentioned problem was determined and analyzed. The specificity of photography, photomontage, photocollage, caricature, illustration, photo-report, photogallery, photo-essay and infographics was outlined in the present article. It was found that in some cases, visual journalism demonstrates significant influence and effectiveness in resolving the humanitarian crisis, although the lines between efficiency and manipulation are sometimes blurred.

Key words: migration crisis, refugees, genre, visual journalism, influence. 
The novelty of the research and its scientific significance. The formulation of the problem and its relation to scientific and practical tasks.

The novelty of this inquiry and its scientific significance is determined by the necessity to investigate the specificity of visual elements in the on-line version of the newspaper and by the need to outline their role in contemporary English-language sociopolitical and journalistic discourse on the topic, in view of the fact that nowadays the study of the visual content in publications is no longer "marginally isolated" from traditional text interpretation. If one considers modern journalism as multimedia journalism, which integrates different media (such as press, radio, television) into process of creating an on-line-publication, it is obvious that in the hierarchical scheme text video - audio photography and its various manifestations has the same significance as the text does.

Furthermore, the influential role of visual component in journalism cannot be diminished, taking into account the resonant photo and caricatures be itpolitical cartoons, such as the caricatures of Donald Trump or Vladimir Putin, or any other cartoons - they provoke scandals and vivid discussions, or (as in the case of the magazine the Charlie Hebdo) even result in a spate of attacks and acts of terrorism by Islamic militant groups, instigated by caricature depiction of Islam and comics about the life of the Prophet, which has led to 12 deaths among editorial staff members with 11 people more being injured.

\section{The aim of the study.}

The article is aimed at investigating the specificity of visual journalism elements in different genres which focus on covering the "refugee crisis", and revealing their influence on the forced migration issue reception. The object of the study is digital copy of The Guardian, which is considered to be one of the best newspapers in the Great Britain, ranked third among all popular news sources in the world. The sampling under analysis includes 
journalistic publications that were issued in the periods of reactivation of covering the "refugee crisis" from 2015 to 2018. As a result, 200 publications from 20 entries (50 texts from every years' archive), featuring the "refugee crisis", were analyzed together with about 500 visual elements.

To complete the research, synchronous, diachronic, descriptive and iconographic methods of analysis were used extensively.

\section{The analysis of resent researches and publications.}

The nature and role of images in the dissemination of news today raise more questions than answers. The idea of searching for answers is materialized in works on the visual journalism of national researchers, such as D. G. Akchurin [1], V. M. Berezin [5], A. A. Karavayeva [9], B. I. Chernyakova $[14 ; 15 ; 16]$, and international scholars J. Baudrillard [6], R. Bart [3], S. Sontag [33], V. Flusser [12] and others. The object of research in their scientific papers are the nature of visual elements, the relation of illustration and text and the genres of visual journalism.

A German scholar, professor of journalism and communication theory, Siegfried Weischenberg [7] considers visual journalism as a process of "creating, selecting, processing and disseminating images in a journalistic sense", that is disseminating information through "visual text", not the linguistic one $[7,4]$.

In fundamental work of the Ukrainian researcher B. Chernyakov it is noted that the peculiarity of the specified field of journalistic activity is manifested in the use of images as the main means of influence on the mass audience and includes the preparation of visual materials for use in the media [16, 34].

With the acknowledgement of visual journalism as a particular field of knowledge in the last century, the exploring of the specificity of its genres became more active. We use the achievements of B. Chernyakov [16], who systematized existing classifications and distinguished genres which are being defined by the use of diverse technical equipment, such as photography, photomontage, photocollage, infographics, caricature, as well 
as combined genres, with reference to using photos to reproduce images created in the traditional way. With the intensive development of the Internet journalism, modern researchers have stated the displacement of verbal content by visual one and diversified typologies of image genres, explaining their transformation into network media, e.g., the longread, etc.

Other arguments include synthesis of texts, intensification of visualization and infotainment trends. I. Tonkih [11] points out that operational images, plot and report photos, photographic illustrations, photogalleries, panoramic photos, collages, photo-essays, infographics, slideshows and caricatures are all separate types of multimedia among static visual genres or media formats $[11,95]$.

\section{The presentation of the main research materials.}

The most common type of visual journalism is photojournalism. A number of famous photos of refugees was created during the migration crisis and made history forever. The focus of such photographs is on the inhumane suffering of refugees. In particular, photos of the body of a threeyear-old Syrian refugee thrown by waves on the Turkish coast have become world-famous (see Annexes 1.1, 1.2). The family of the boy died trying to cross Mediterranean Sea in order to find refuge in Europe as well as failed to obtain refugee status and to get asylum in Turkey where they used to live.

Among the national opposition and pro-governmental newspapers, only The Guardian and The Independent published these images unchanged. The Mirror, The Express, and The Mail websites used body pixelated versions or (like Daily Star) darkened the head. The Telegraph and The Financial Times decided to do the same as the $B B C$ but did not publish the most shocking photo of the boy's body lying face down on the sand in the central part of the photo.

Each lead paragraph in The Guardian was followed by the warning that the publication containes images that may cause anxiety, conforming publications with the rules of their own editorial policies and justifying 
the placement of the photo as "being of a high public interest", which appeared to be the most obvious to researchers [31]. "We must always ensure balance between the public interest in full and accurate information and the need tobe compassionate and to avoid any unjustified breaches of privacy when reporting accidents, natural disasters, riots or war", BBC Editorial Guidelines state [10,51].

The controversy triggered by the discussion over the appropriateness of such publications in the journalistic environment has raised various comments and reactions. So, in the Ian Jack's article "Can images change history?" [24] it is mentioned that such photographs can change our perception, so usually only the most shocking and terrifying photos are used for publications. At the same time, he points out that the photos of Aylan differ from other shocking images which have already made it into history due to the lack of aesthetic, monochrome reproduction, the weakness of photographer's skills. But in this case, according to author, aesthetics does not matter: "Artless but honest pictures can still change our perceptions of the world" [24]. Still it should not be assumed that personal prejudices and desires play no role in the process of their creation or influence: "Wouldn't images of young men with their heads blown off have ended the first world war sooner? Should we have seen pictures of the 116 dead children as they were pulled from the mudslide of Aberfan? Why aren't there well-known images of the thousands of children who were charred in Dresden and Hiroshima? We pick and choose among the images that might horrify us, always believing that our intentions are good" [24]. So, that is exactly the kind of photos that influence public opinion and "awaken" the recipient, though everyday perception of a terrible reality can contribute to the transformation of suffering into a commodity, and photographs illustrating the death of a child can be used for personal or professional benefit, etc.

The photographer who took the photos of the boy's body, emphasized in her interview that the photos of the incident had been taken by chance at 
six o'clock in the morning, so they were not intended to be aesthetical and artful, thus this fact explains her aim to become the "voice of the dead" and to help solve this problem [32].

J. Valle claims, that "some images can affect the viewer, as if leaving a mark in their memory, as an emotional tattoo that impresses us and can remain in memory for the rest of our lives" [36]. In other words, a wellchosen photo has considerable pragmatic potential and is able to stay longer and more secure in reader's memory, both as the visual image and the basic idea of a text message that accompanies the photo. Editor-in-chief Catherine Wiener explained their editorial approach: "It was very important for us to show Aylan's death in the context of serious reports of what happened to him and a broader picture of contemporary political and social attitudes towards refugees across Europe, especially in Britain and Germany. I still think that we used the photos correctly but I can be wrong because I know that good and serious intentions are not always enough" [36].

The pictures emerged on the day David Cameron closed the door to accepting more Syrian refugees. Such words have only exacerbated the feeling of imminent humanitarian catastrophe in Britain and other countries.

It was the social context that helped The Guardian to create a defining image of the refugee. By the time Aylan's photos were published, there had already been enough information known about the "refugee crisis": countless amount of people had died in their desperate attempts to get to the safe haven that Europe had been serving but it was the photos that served cruel, candid evidence, that forced people to look at the things previously ignored and silenced. Therefore, the use of overtly shocking images of the dead boy was driven by the need to sufficiently cover the "refugee crisis", to reflect the severity and significance of the problem.

Thus, the photos caused a tempestuous debate and had immediately travelled all around the world: the number of social media reposts exceeded 
20 million in the first 12 hours. The impact on the Great Britain and the US was particularly significant. The distribution of press photos has contributed to the growth of financial support for Syrian refugees: there have been reports from charities and NGOs that the number of donations from those countries has increased by $3000 \%$. Public resonance has led to dramatic changes in refugee policies in many countries, including the United States, the United Kingdom, Canada, Australia and Central Europe, and these photographs were considered among the most influential of all time.

Along with the publications that combine verbal and visual components, the newspaper under analysis contains a great number of journalistic materials of different genres of specifically visual nature, such as photogallery and photo-report, which constitute a separate type of narration that is basically "a photo story about the event". A photogallery contains photos that are not related to the general theme but are combined by a shared title such as "Photos of the Week" with extended comments to each photo, while a photo-report contains photos, which illustrate the same event and are created by one author. Navigation in both cases is organized equally: the user flips picture after picture.

One of the popular versions of the photogallery in the edition is a collection called " 20 photos of the week", which at the same time serves as a permanent independent heading. For example, in a compilation published on October 24, 2015, 5 photos out of 20 depict refugees and describe forced migration [28]. One of them, the image of a woman with children sleeping on the grass, is repeated twice as it is also placed at the top of the webpage before the title and date of publication. In the final photo of that week, the author returns to the "refugee crisis" in Europe, adding the following comment: "Here, migrants and refugees arriving from Croatia wait for buses in the town of Zavrc on the Slovenian-Croatian border. More than 12,600 migrants arrived in Slovenia over a 24-hour period last week, police said, a record that surpasses even that of Hungary at the height of the crisis 
in September. More than 600,000 migrants and refugees, mainly fleeing violence in Syria, Iraq and Afghanistan, have braved the dangerous journey to Europe so far this year" [28] (see Annexes 1.3, 1.4).

The headline "Phoho highlights of the day: abseiling, protests and dog racing" [29] captures the main topics of the photos — out of 13 photographs, 2 depict refugees.

A special feature of photogalleries which cover "refugee crisis" is that images there are of a better quality than those illustrating journalistic materials, as well as more profound and poignant if talking about content, since they are not usually created by photojournalists, editors or journalists, but by professional photographers for whom photos are art and not a visual impact tool. Such photos require a high level of professionalism, creativity and incredible mastery. Typically, photographers publish their works on special hosting sites that function as global digital media providers and distribute photo, audio and video content.

For example, The Guardian cooperates with photo hosting Getty Images, the largest photo agency in the world with over 200 million photos. Most of the images are not copyrighted and may be freely used by journalists. If it is necessary to use the photo which is forbidden to reprint the newspaper staff have to reach agreement on using images with the author personally. But in general, author of the photos can select the best of his/her works for publication on a hosting that provides high quality photo materials, and journalists have the ability to effortlessly pick images to any text message, as well as easily create photogalleries of various thematic focus.

In the lead paragraph of the photo-report "Distant shores: tourists and refugees on Kos - in pictures" [21] the time and place of the event, as well as the author are defined: "This summer, record numbers of refugees and tourists shared the beaches of Kos. Photographer Jörg Brüggemann saw two worlds meet" [21]. To explain the meaning of the photos, the photographer uses a visual technique of comparison, each of the elements 
being compared with the other: the paddlers may be tourists or Syrians coming from Turkey; tourists are taking photos with a ferry where hundreds of refugees are waiting to submit documents in order to go to mainland Greece. Another photo shows a tourist taking selfies in front of the refugee camp; life jackets are scattered on the coast near the recreation areas in the next shot. Consequently, the idea behind the photo-report is only revealed in coherence and collision of the various elements of the form with the macrocontext. Contrasts, analogies and differences are only visible through comparison (see Annex 1.5).

Some photo-reports are examples of civic journalism, such as the "\#LightTheDark: readers share their photos from around Australia" [34]. Thousands of people attended a candlelight march to urge world leaders to take action on resolving the humanitarian crisis caused by the conflict in Syria. The event was held in protest of the refugees' suffering. A separate webpage is dedicated to a photographic report of the candlelight march with the photos sent by the readers (see Annex 1.6).

On the web pages we also find a photoessay. In particular, the publication "Keleti to Austria on foot: the journey that transformed Europe's refugee crisis - in pictures" [30] is a photo series with brief comments that are aimed at having a significant emotional impact on the recipient. The author tells the story about a crucial point in Hungarian history when hundreds of men, women and children departed from the Keleti station in Budapest to the Austrian border in order to find shelter. In the photoessay, the pictures are accompanied by a text commentary, which becomes an equal (like an image) means of forming the story of the event (see Annex 1.7): "This picture shows a woman and her child crossing the no man's land between the Hungarian and Austrian border. Despite making it out of Hungary, there was no celebration that I saw, maybe because it was just another part of a long journey for them. On the Austrian side of the border, medical staff and volunteers were there to distribute food and medical treatment if needed. It 
was like night and day compared with Hungary." [30]. And if in the case of photo-report the commentary has a supporting role, the text and the photo are equivalent and complement each other in photoessay.

Although caricature is traditionally considered as a print media genre, it gets new meaning in the studied newspaper as a stand-alone work in visual journalism, with its own subject matter, specific irony and satire and special role of the text. According to M. Balaklitsky: "Word in a shot is an extremely powerful tool for influencing the viewer. None of the inscription under photo even compares with it. The text in the photo intensifies the image's message" $[2,10]$. Moreover, the well-known researcher S. Gorevalov regards the caricature as one of the three pillars of visual journalism, along with photography and infographics [8, 257]. The caricatures featured in the online edition are not traditionally created (by drawing on paper) but with the use of computer graphics. Their objects of depiction are famous politicians and/or their actions in the context of dealing with refugees' problems. For example, the professional cartoonist Steve Bell's political caricature contains an allusion to the most famous comic book character, Superman (see Annex 2). Taking into account the well-known fact that Clark Kent's character used a telephone booth to quickly become Superman, the author portrays David Cameron in the telephone booth in the foreground and draws a cloud with the text, that makes it possible to read his thoughts: "This work is for..." [21]. In the background there is another booth from which not Superman but Somebodyelseman dressed as Superman flies out with words: “I'm deeply moved!". Thus, the cartoon's main message is that David Cameron is not going to become a superhero to solve refugee problems, but rather relies on the mysterious Other. The caricature element (the telephone booth) symbolizes the pro-governmental media that creates the distorted image of an ideal political leader. The cartoon appeals to the emotions of the readers, forms a subconsciously negative picture of the political leader. 
In the coverage of the "refugee crisis" images made by traditional means in the technique of drawing are actively used, followed by photographing them for presentation on the website of the newspaper's online platform. The peculiarity of illustrations analyzed in the study is that they are the result of the active participation of the readership in journalism. An example is the social photo project "\#3000chairs: the empty chairs of Syrian child refugees - in pictures" [22], which presents the reaction of illustrators, writers and children on the poem "War Day" by Nicholas Davis. The poem is dedicated to the 3,000 Syrian children left without refuge by the UK government during the crisis. The publication encourages anyone, who is outraged, to draw, photograph, or even embroider an empty chair and share it on Twitter and on the newspaper's website with the hashtag \#3000chairs. As a result, the social protest has got a form of compilation of original illustrations of chairs posted on the Internet. In fact, the website of the newspaper has become an interactive visual gallery of illustrations with the inscriptions and comments of the authors (see Annexes 4.1, 4.2). The illustrations created by the readers are characterized by a high degree of emotionality and expressiveness in comparison with other genres of visual journalism and are inextricably linked to the pragmatic attitude of each individual author, which is determined by the purpose of the project itself and the position of the newspaper as a social platform for presenting the opposite viewpoint and peaceful protest.

An interesting way of expressing the author's vision of the issue in the edition is the use of photocollage (see Annex 3 ) and photomontage (see Annex 5), both genres characterized by merging pictures in order to achieve a certain effect - they are quite rare among the analyzed publications. Both are visual genres of secondary order because the process of their creation is basically the operation with works that has already been prepared in terms of photographic engineering. S. Gorevalov explained the difference between them: "In photomontage, these plots are made in a photographic way, unlike 
in a photocollage applying visual synthesis way with the help of illustrations and computer graphics" [8, 258]. Unlike photos, illustrations, cartoons and graphics, which are characterized by a momentary reflection of reality, the genres of photocollage and photomontage are complex and multifaceted because they are created by combining different visual representations on a common picture plane.

The example of a significant photomontage is the one, published in two articles of the newspaper $[25 ; 35]$ - the montage of the photos of Angela Merkel and Donald Trump, who in 2017 were proponents of two opposing points of view on the complex and delicate subject of refugee admittance to other countries. The interpretation is facilitated by the inscription under the image in the form of a quote, which immediately makes readers understand the viewpoints of each of the political leaders: "Her open-door policy on Syrian refugees was a catastrophic mistake. How could she give up control of her country's borders, taking in all those illegals?" [35] (see Annex 5). It becomes clear that this is a combination of photographs of people who, by virtue of their diametrically opposed views, will never reach a consensus on the admission of refugees. The technique of comparison is effectively used in a wholly unexpected way, combining photos of two world-famous politicians, with the author being able to clearly outline the key thoughts of leaders about the crisis, using contrast in showing two opposing points of view, which are also thoroughly analyzed in the publication. Hence, photomontage captures the author's intention and serves as a powerful suggestion tool.

Photocollage and photomontage account for only $6 \%$ of the total articles analyzed.

Publications which cover the "refugee crisis" use infographics that is closer to multimedia journalism than to visual one. Infographics systematize information in the form of tables, graphs, diagrams and is considered as static genre, aiming at facilitating the perception of information, accurate reproducing of certain processes and showing their consequences. Some 
publications feature animated infographics that is different from the static presentation of interactive elements as it may have the form of a slide show or audio commentary.

In 2009, a journalist Simon Rogers founded The Guardian Datablog, a project aimed at combining data, statistics and visualization into a wholesome information product. The development team has invented the way to use new technologies in combining of different data sets in an accessible and concise way to convey important news, avoiding the use of traditional book formats (PDFs) which need to be downloaded on a certain device.

The editors of the newspaper noted the trend that the rapid increase in the amount of Internet resources and the amount of information data made readers from all over the world interested in information and facts that are based on news that is difficult to fake and manipulate. The authentic format of the infographic in the paper with the help of visualization and multimedia allows readers to return to the independent perception and interpretation of objective, reliable information without emotional and pragmatic influence that could cause a subconscious valuation of the events presented in pictures of different genres. With the help of Datablog the newspaper harmoniously integrated statistical and sociological data into its news production process.

In the text "How does UK refugee commitment compare with other countries?" [27], the author cites a great deal of data regarding the European Commission's expected proposal for resettling refugees from Italy and Greece to different countries, compared to the acceptable amount agreed by EU Member States and which turned out to be much lower than desired. The text was based on data obtained from the Eurostat's statistical service, presented in the form of graphical images and diagrams. These indicators made it possible for the author to calculate the number of refugees to be accepted by each EU Member State according to the plan developed and the quotas allocated by them. It is the use of graphs and charts that has allowed to create a fully transparent (in terms of the sources and data used) grid of 
the number of refuge seekers that each country should receive. In the future, this information will allow the community and the media to control the implementation of decisions by the authorities, based on the data published in the article. An important element of infographic style in the publication is the use of colors, which not only attracted reader's attention to the difference in the planned and actual quantitative rates of accepted refugees, but also helped to visually group condensed information from different sources on a small plane (see Annex 6).

Better visual contrast has been achieved with the organization of data in the form of horizontal and vertical blocks, clearly separated from each other to avoid overly dense text, which could complicate its perception by readers. The monodirectional mode of the style in the creation of infographics, the absence of excessive color and font highlights and harmonious unification of animation focuses reader's attention on important points and facilitates the perception of information.

\section{Conclusions and prospects of the further research.}

Hence, taking into account the wide range of ways of informing used by The Guardian (infographics, data visualization, interactive visualization), we can speak of an effective combination of verbal and visual multimedia format. Firstly, the visual component is used as an element of hypertext in the form of additional facts which provide in-depth informative materials. Secondly, it is represented by a significant spectrum of genres of a particular type of journalism, the visual journalism, which testifies the development of their own style of informing and spreading horizontal communication, actively involving the society in dialogue. In this case, the genres of visual journalism are used both as a "foundation" for storytelling and as reasoned visualization, particularly when there is something which is difficult to describe. All genres are characterized by varying degree of emotionality and suggestiveness, even with elements of shock, but are correlated with editorial politics, journalistic standards, public interest and 
the desire to solve global problems even when society remains indifferent. The effectiveness of the texts in the newspaper has been proved by certain social development, adjustments to EU policies and practical solutions of refugee problems.

The results of the research are of value to further study of visual media suggestibility/manipulativeness, its effectiveness in the coverage of the global political and social issues and community formation, as well as the impact of multimedia on the genre nature of journalistic texts. 
ANNEX 1

\section{PHOTOGRAPHY}

Annex 1.1

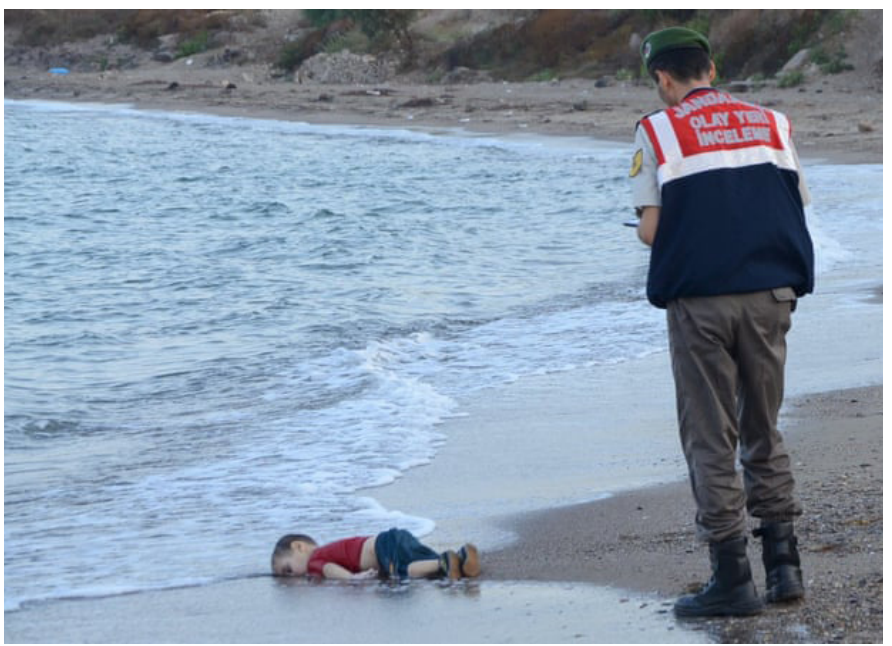

Photograph: Reuters 'Smith H. Shocking images of drowned Syrian boy show tragic plight of refugees' [32]

Annex 1.2

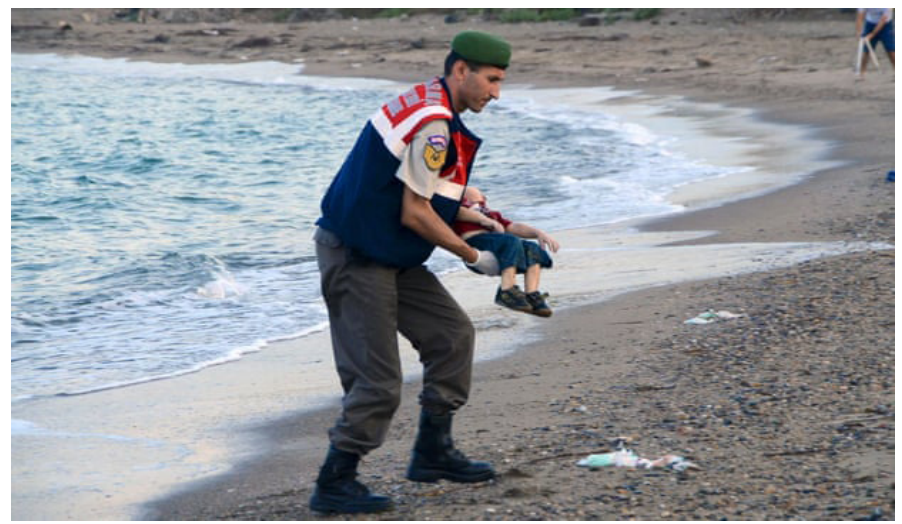

Photograph: Reuters 'Smith H. Shocking images of drowned Syrian boy show tragic plight of refugees' [32] 
Annex 1.3

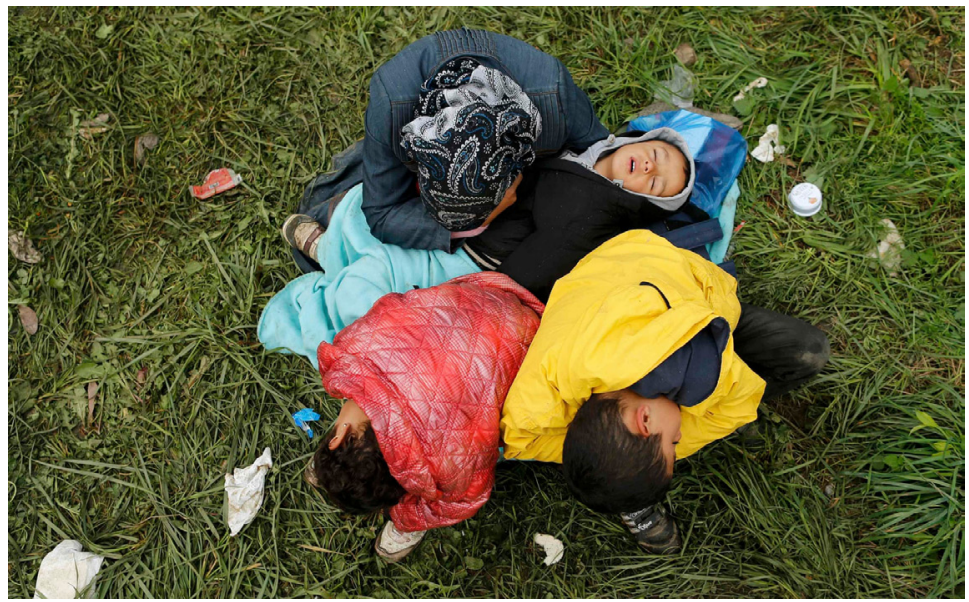

Photograph: Antonio Bronic/Reuters

'The 20 photographs of the week' [28]

Annex 1.4

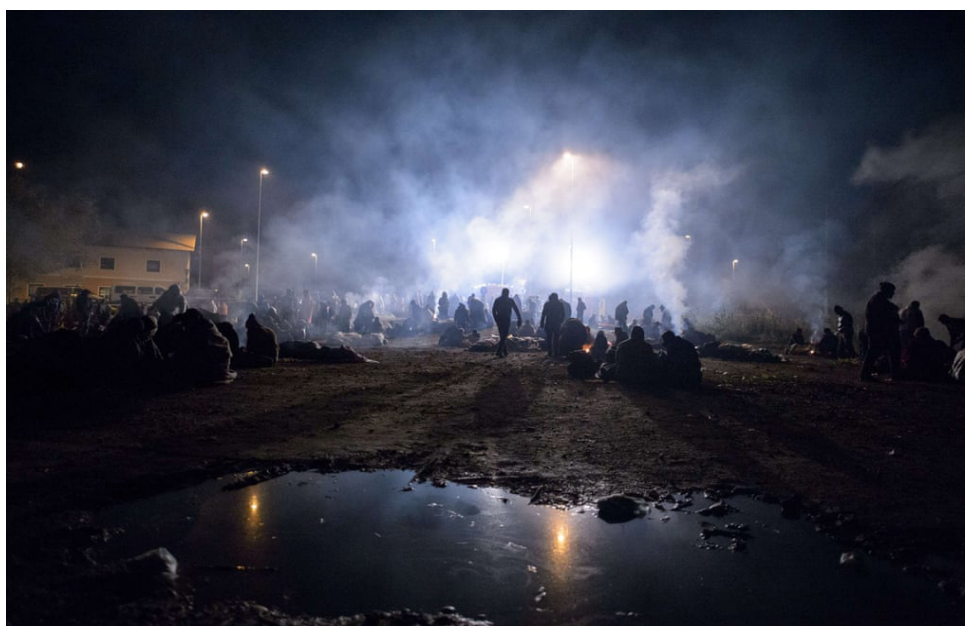

Photograph: Rene Gomolj/AFP/Getty 'The 20 photographs of the week' [28] 
Annex 1.5
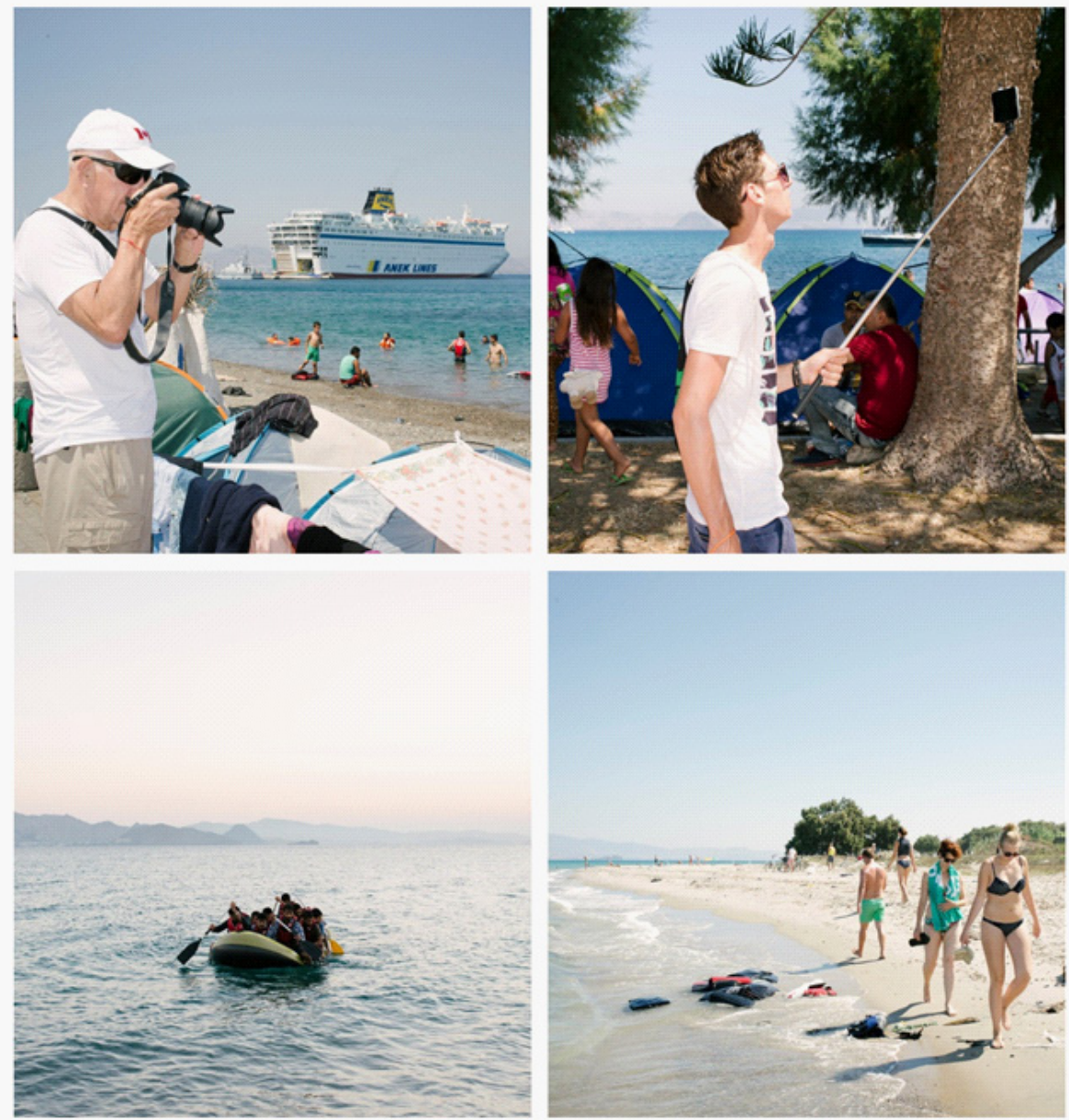

Photographs: Jörg Brüggemann 'Distant shores: tourists and refugees on Kos - in pictures' [21] 
Annex 1.6

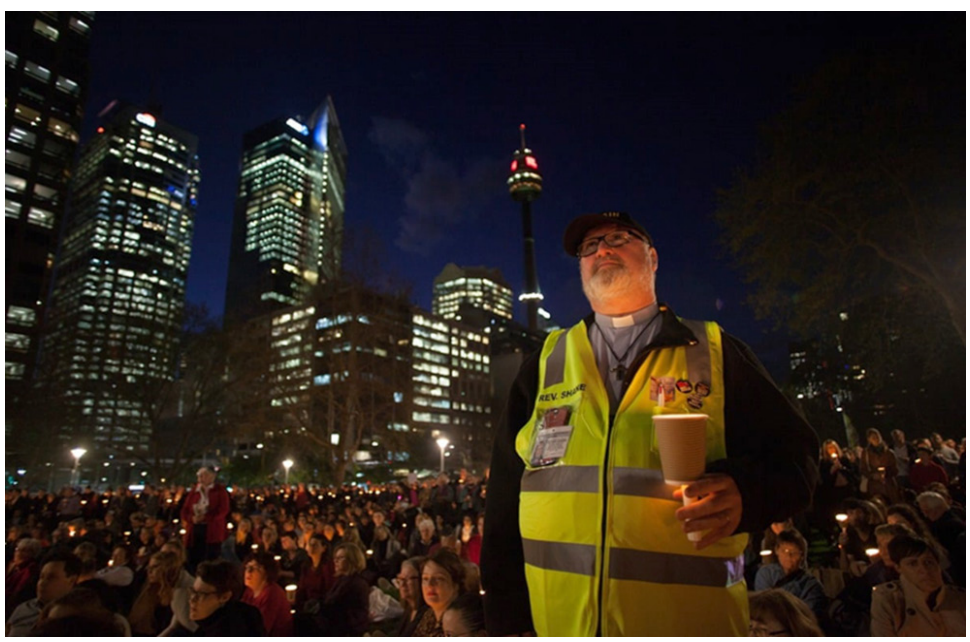

Photograph: Tahsin Rahman/GuardianWitness '\#LightTheDark: readers share their photos from around Australia’ [34] 
Annex 1.7
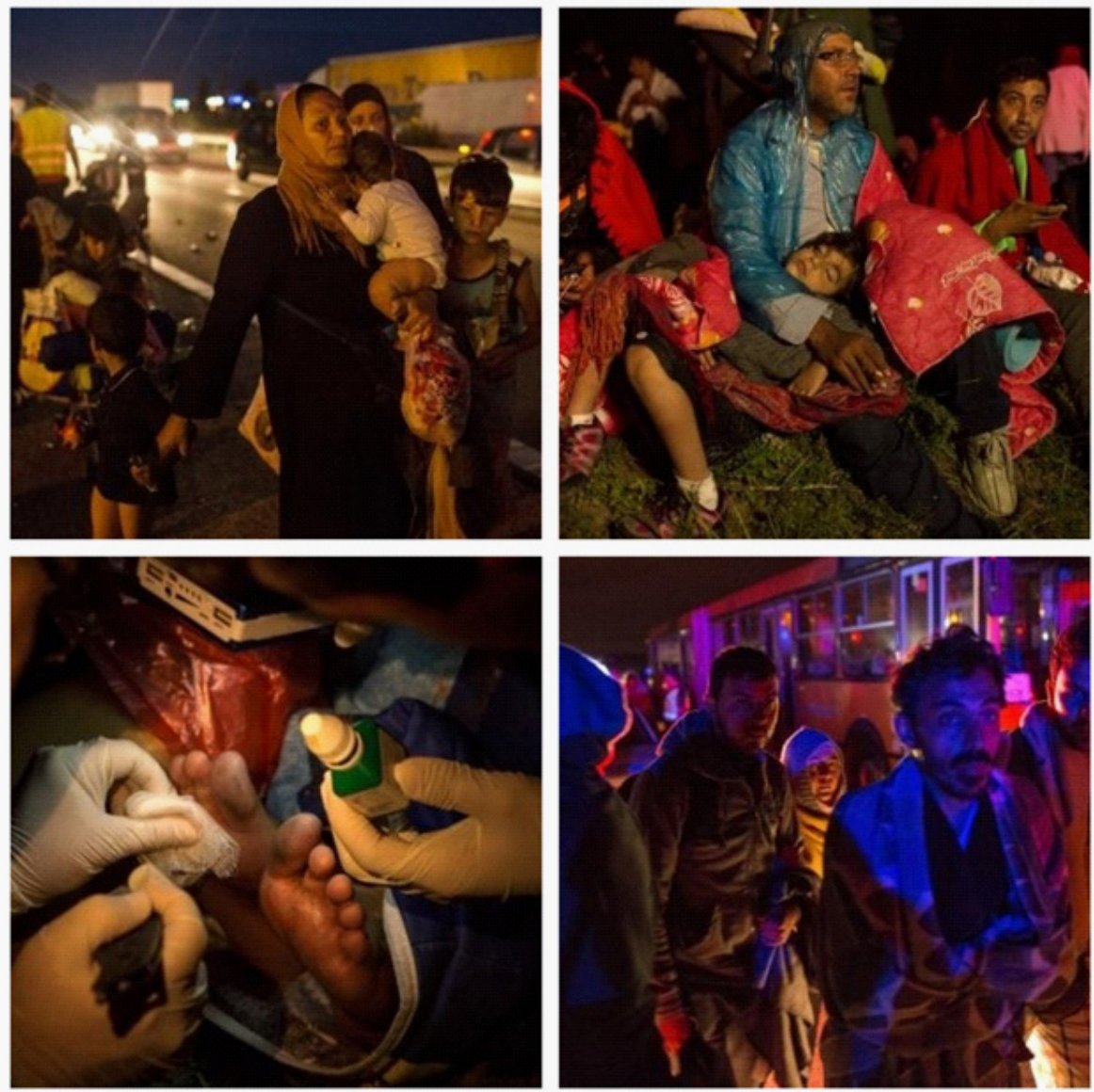

Photographs: David Maurice Smith 'Keleti to Austria on foot: the journey that transformed Europe's refugee crisis - in pictures' [30] 


\section{CARTOON}
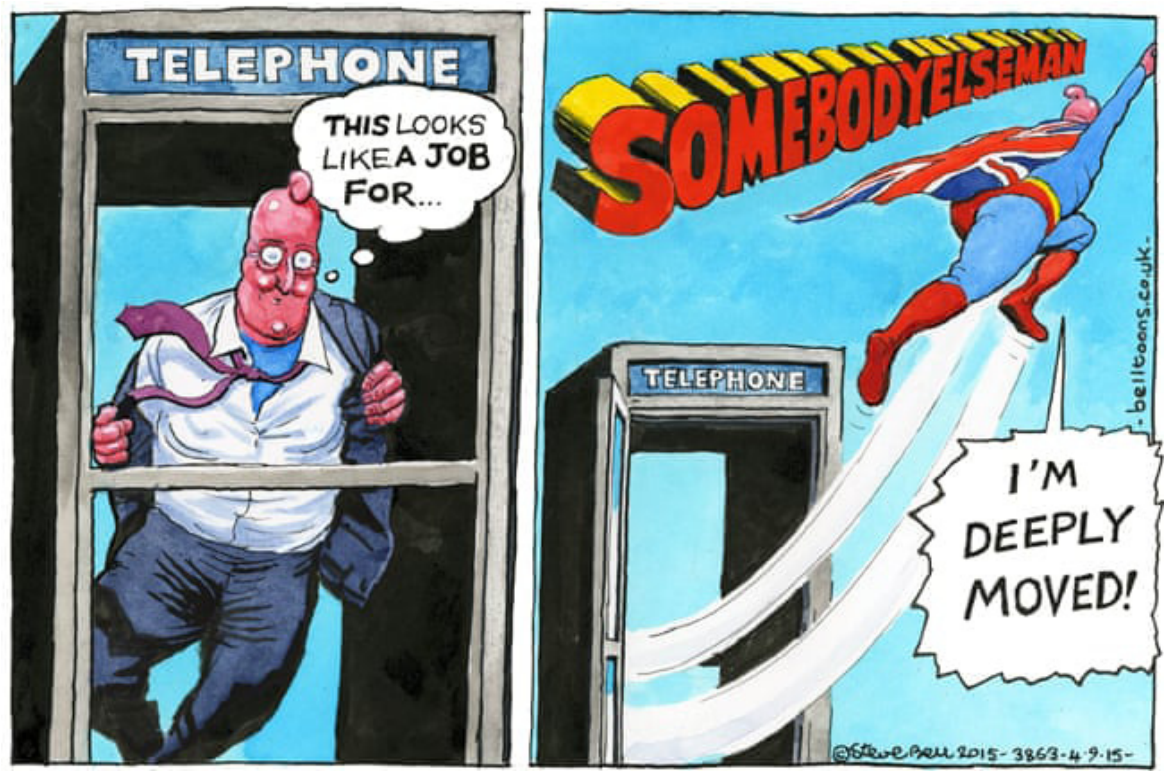

Steve Bell 'David Cameron's response to the refugee crisis - cartoon' [20] 
ANNEX 3

\section{PHOTOCOLLAGE}
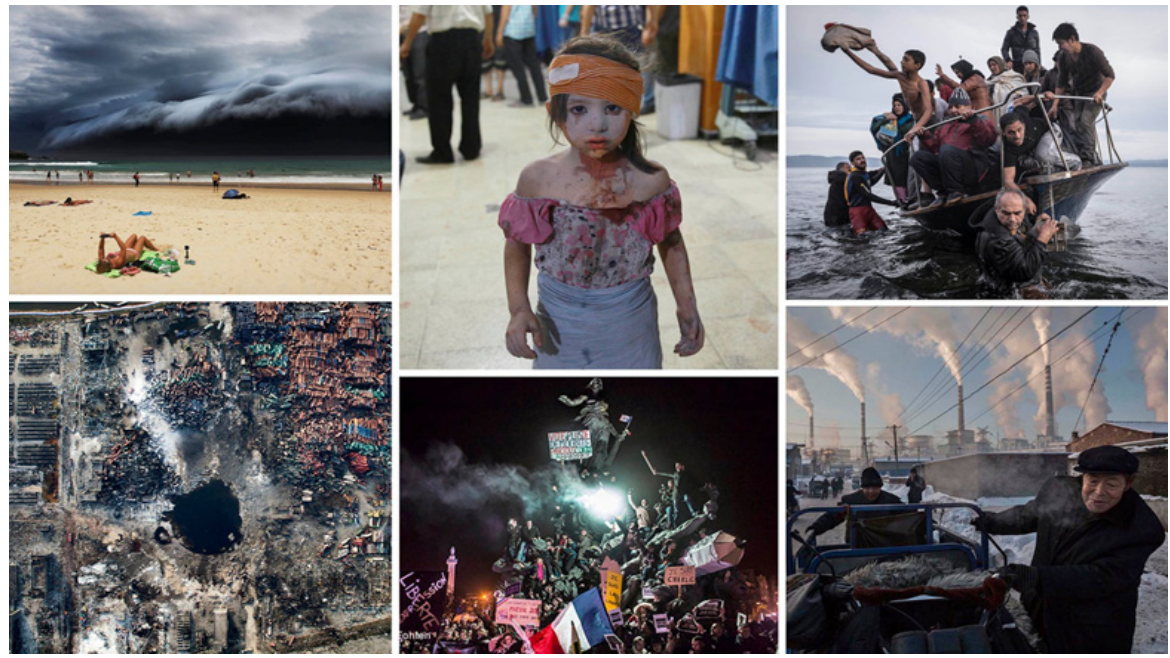

Kim J. 'World Press Photo 2016 winners - in pictures' [26] 


\section{ANNEX 4}

\section{ILLUSTRATION}

Annex 4.1
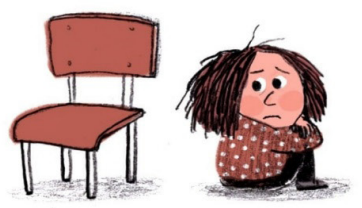

\#3000Chains

marta altér
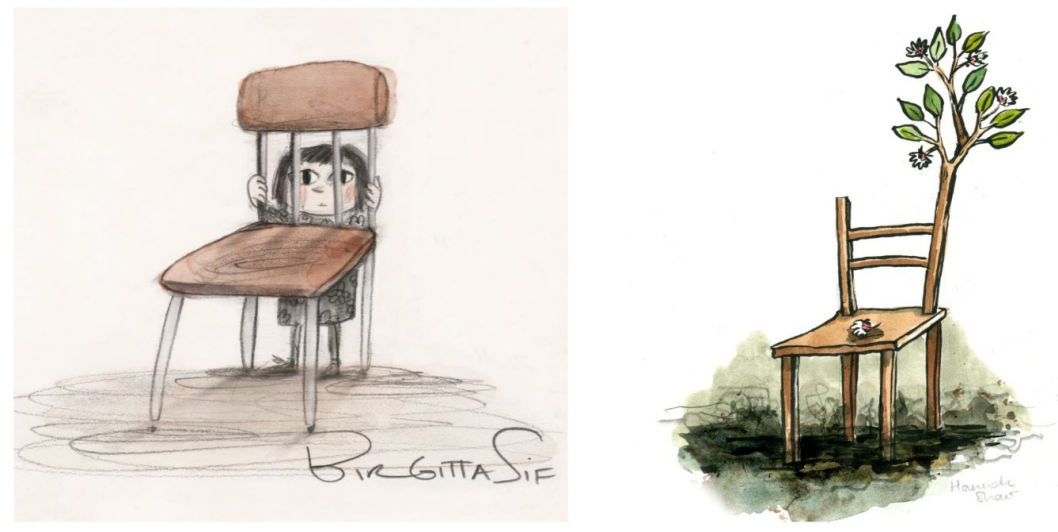

Illustrations: Marta Altes, Birgitta Sif, Kristyna Litten, Annah Shaw '\#3000chairs: the empty chairs of Syrian child refugees - in pictures' [22] 
Annex 4.2

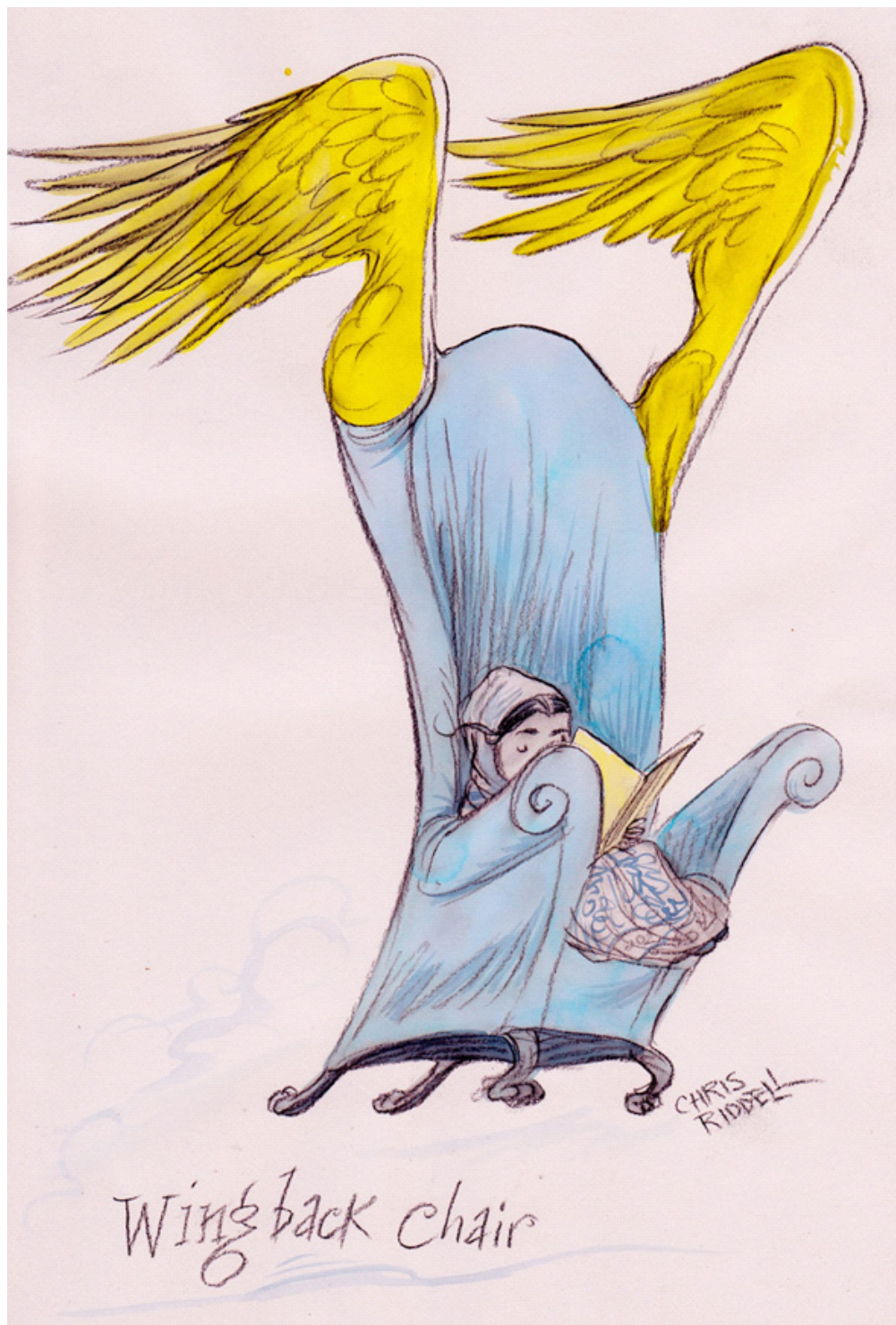

Illustrations: Chris Riddell ' \#3000chairs: the empty chairs of Syrian child refugees - in pictures' [22] 


\section{PHOTOMONTAGE}
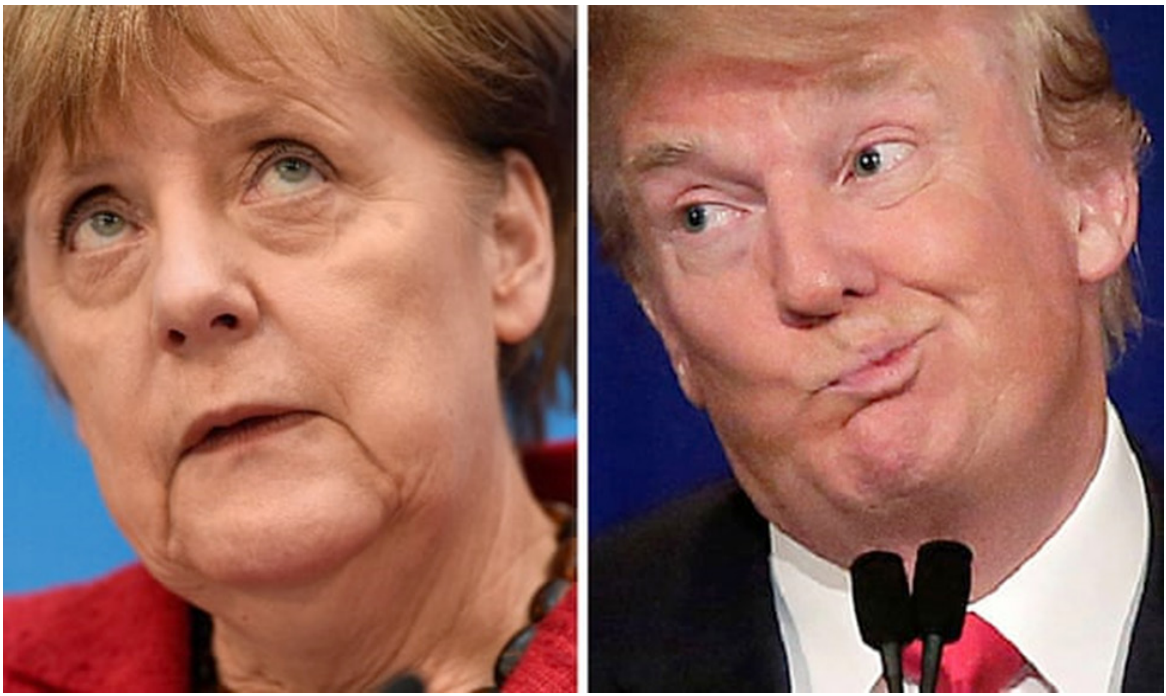

Photograph: Odd Andersen/AFP/Getty Images 'Trump doesn't let facts get in the way of immigration scare stories. He's not alone' [25, 35] 
ANNEX 6

\section{INFOGRAPHICS}

\section{Relocation of refugees}

Key:

$\square$ European Commission proposal to relocate 40,000 refugees from Italy and Greece

Relocation numbers agreed by member states

- Expected European Commission proposal to relocate 120,000 refugees from Italy, Greece and Hungary

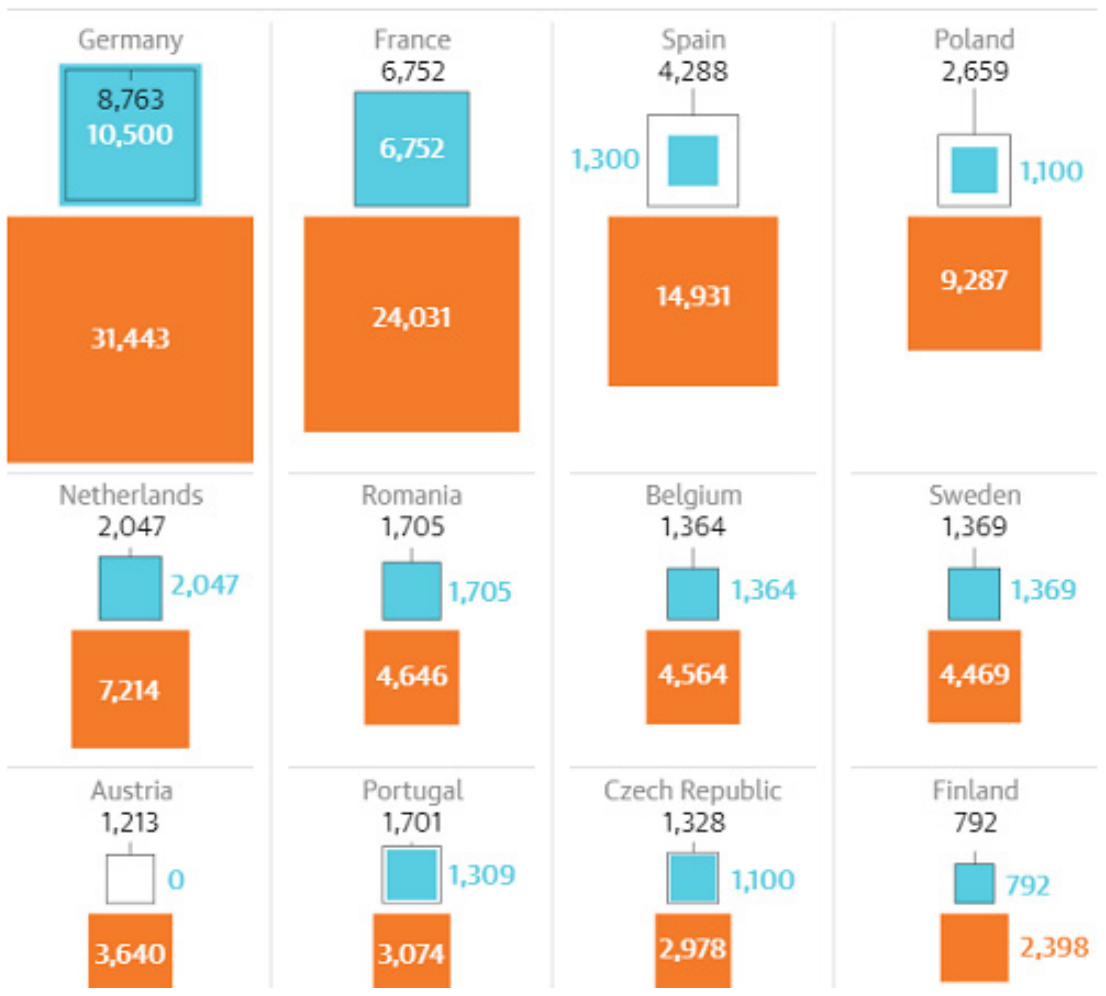

Source: European Commission, Guardian calculations 'How does UK refugee commitment compare with other countries?' [27] 


\section{Література:}

1. Акчурин Д. Г. Основы современной фотожурналистики : учебн. пособие. Киев : КГУ, 2012. 232 с.

2. Балаклицький М. А. Зображальна журналістика : навч.-метод. посіб. для студентів зі спеціальності «Журналістика». Харків : ХНУ імені В. Н. Каразіна, 2019. 84 с.

3. Барт Р. Система моды. Статьи по семиотике культуры. Москва : Издательство им. Сабашниковых, 2003. С. 378-392.

4. Беньямин В. Краткая история фотографии [эссе]. Москва : Ад Маргинем Пресс, 2013. 78 с.

5. Березин В. М. Фотожурналистика : учебн. для академ. бакалавриата. Москва : Издательство Юрайт, 2019. 252 с.

6. Бодрийяр Ж. Фотография, или Письмо света / пер. с англ. Арсен Меликян. URL: http://cs5.a5.ru/media/6e/20/49/6e204984c118847b3a389 be9cefcf83c.pdf (дата звернення: 6.05.2019).

7. Вайшенберг 3. Журналістика та медіа : довідник / 3. Вайшенберг, Г. Кляйнштойнбер, Б. Пьорксен. Київ : Академія української преси, Центр вільної преси, 2011. 529 с.

8. Горевалов С. І., Зикун Н. І. Жанри фотожурналістики в умовах посилення тенденції візуалізації ЗМІ. Наукові записки Інституту журналістики. 2014. Т. 56. С. 257-261.

9. Караваєва А. А. Фотопубліцистика періоду Великої Вітчизняної війни 1941-1945 рр. : Москва, 1981. 317 с.

10. Редакційні настанови «Бі-Бі-Сi». URL: http://www.bbc. co.uk/ukrainian/indepth/story/2005/11/051125_bbc_ukraine.shtml (дата звернення: 6.05.2019).

11. Тонкіх І. Ю. Інтернет-журналістика. Жанри в інтернеті : навч. посіб. URL: https://mail.rambler.ru/m/folder/INBOX/12486.3/download/ id/Tonkikh_Internet-Journ (дата звернення: 6.05.2019).

12. Флюссер В. За философию фотографии. Санкт-Петербург : Изд- 
во СПетерб. ун-та, 2008. 146 с.

13. Черкова А. И. Таймлайн как специфический вид журналистского творчества в Интернете : теория и практика. Знак. Проблемное поле медиаобразования. 2014. № 2 (14). С. 112-124.

14. Черняков Б. І. Зображальна журналістика в друкованих засобах масової інформації від виникнення до середини XIX століття: автореф. дис... д-ра філол. наук. Київ, 1998. 37 с.

15. Черняков Б. І. Ілюстрована книжкова періодика у процесі становлення ранньої зображальної журналістики. Київ : Київський ун-т імені Тараса Шевченка, Інститут журналістики, Центр вільної преси, $1998.155 \mathrm{c}$.

16. Черняков Б. И. Фотография в изобразительной журналистике: генезис технических и творческих возможностей. Киев : Институт системных исследований образования, Киевский ун-т им. Тараса Шевченко, 1996. 119 с.

17. Шендеровський К. С. Медіакомунікації та соціальні проблеми : зб. навч.-метод. матеріалів і наукових статей в трьох частинах. Частина перша / упор., ред. К. С. Шендеровського. Київ, 2012. 288 с.

18. Штомпка П. Введение в визуальную социологию. ИНТЕР. 2007. Tом. 1. № 4. C. 6-12.

19. Barr C. A decade of the Datablog : 'There's a human story behind every data point'. URL: https://www.theguardian.com/membership/ datablog/2019/mar/23/a-decade-of-the-datablog-theres-a-human-storybehind-every-data-point (дата звернення: 18.11.2019).

20. Bell S. Steve Bell on David Cameron's response to the refugee crisis - cartoon. URL: https://www.theguardian.com /commentisfree/ picture/2015/sep/03/steve-bell-david-cameron-refugee-crisis-cartoon (дата звернення: 11.16.2019).

21. Brüggemann J. Distant shores : tourists and refugees on Kos in pictures URL: https:/www.theguardian.com/world/gallery/2015/sep/04/ 
distant-shores-tourists-and-refugees-on-kos-in-pictures (дата звернення: 15.10.2019).

22. Drabble E. \#3000chairs : the empty chairs of Syrian child refugees - in pictures URL: https://www.theguardian.com/ childrens-books-site/gallery/2016/may/03/3000chairs-empty-chairs-ofsyrian-refugees (дата звернення : 20.10.2019).

23. Editorial Guidelines. Guardian News \& Media Editorial. URL:https:// www.theguardian.com/info/2015/aug/05/the-guardians-editorial-code (дата звернення: 18.11.19).

24. Jack I. Can images change history? URL: https://www.theguardian. com/commentisfree/2015/sep/04/images-aylan-kurdi-syria (датазвернення: 11.06.2019).

25. Joffe J. Trump has bared his fangs to Merkel. He will do untold damage to Europe. URL: https://www.theguardian.com/commentisfree/2017/jan/17/ trump-merkel-europe-brexit-putin-nato (дата звернення: 23.10.2019).

26. Kim J. J. World Press Photo 2016 winners — in pictures. URL: https://www.theguardian.com/media/gallery/2016 /feb/18/world-pressphoto-2016-winners-in-pictures (дата звернення: 10.10.2019).

27. Nardelli A. How does UK refugee commitment compare with other countries? URL: https:/www.theguardian.com/news/datablog/2015/ sep/08/uk-refugee-plan-comparison-european-countries (дата звернення: 23.10.2019).

28. Powell J. The 20 photographs of the week. URL: https://www. theguardian.com/artanddesign/gallery/2015/oct/24/the-20-photographs-ofthe-week (дата звернення: 16.10.2019).

29. Rees-Bloor N. Phoho highlights of the day : abseiling, protests and dog racing. URL: https://www.theguardian.com/world/gallery/2015/sep/07/ photo-highlights-of-the-day-abseiling-protests-dog-racing-refugee-crisis (дата звернення: 26.11.2019).

30. Smith D. M. Keleti to Austria on foot : the journey that transformed 
Europe's refugee crisis — in pictures. URL: https://www.theguardian.com/ world/ng-interactive/2015/sep/10/keleti-to-austria-on-foot-the-journeythat-transformed-europes-refugee-crisis-in-pictures (дата звернення: 28.11.2019).

31. Smith H. Alan Kurdi : friends and family fill in gaps behind harrowing images. URL: https://www.theguardian.com/world/2015/sep/03/ refugee-crisis-friends-and-family-fill-in-gaps-behind-harrowing-images (дата звернення: 24.10.2019).

32. Smith H. Shocking images of drowned Syrian boy show tragic plight of refugees. URL: https://www.theguardian.com/world/2015/sep/02/ shocking-image-of-drowned-syrian-boy-shows-tragic-plight-of-refugees (дата звернення: 5.11.2019).

33. Sontag S. On photography / S. Sontag. New York : Dell PublishingCompany, 1977. 207 p.

34. Stevens T. \#LightTheDark : readers share their photos from around Australia. URL: https://www.theguardian.com/australia-news/gallery/2015/ sep/08/lightthedark-readers-share-their-photos-from-around-australia (дата звернення: 10.09.2019).

35. Taylor D. Trump doesn't let facts get in the way of immigration scare stories. He's not alone. URL: https://www.theguardian.com/ commentisfree/2017/jan/16/donald-trump-immigration-fake-news-uspresident-elect-asylum-seekers-europe (дата звернення: 23.10.2019).

36. Valle J. M. Imágenes-tatuaje. Mensaje y Medios, 1978. 47 p. 


\title{
Изобразительная журналистика и ее жанры в освещении проблемы «кризиса беженцев» английскими изданиями (на примере издания «The Guardian»)
}

\author{
Алла Коваленко, \\ канд. филол. наук, доцент кафедри периодической пресы и \\ медиаредактирования \\ Одесского национального университета имени И. И. Мечникова \\ e-mail:longms@rambler.ru
}

\section{Наталья Алексеева, аспирант кафедры грамматики английского языка Одесского национального университета имени И. И. Мечникова e-mail: natalie.m.alekseeva@gmail.com;}

В процессе написания статьи и исследования освещения СМИ социальной проблемы «кризиса беженцев» в европейских странах осуществлялся мониторинг журналистских материалов газеты «The Guardian». Было определено и проанализировано влияние визуальных компонентов материалов на восприятие читательской аудитории в отображении вишеупомянутой проблемы. Определено специфику фотографии, фотомонтажа, фотоколлажа, карикатуры, рисунка, фоторепортажа, фотогалереи, фотоэссе и инфографики в издании. Установлено, что в отдельных случаях изобразительная журналистика демонстрирует значительное влияние и эффективность в решении вопроса гуманитарного кризиса, хотя грань между эффективностью и манипуляцией очень зыбкая.

Изобразительный компонент в издании благодаря отдельно созданному информационному банкингу «The Guardian Datablog» используется и как отдельная единица информации, и как вспомогательный элемент гипертекста в мультимедиа, и как отдельный способ нарации, и как средство эмоционального 
и эстетического воздействия, а также социального инжиниринга, формирования отдельных комьюнити. Кроме этого, такие хостинги позволяют представителям разных профессий и социальных групп использовать изобразительный компонент в своих материалах и развивают гражданскую журналистику.

Ключевые слова: миграционный кризис, беженцы, жанр, изобразительная журналистика, влияние.

УДК 007: 304: 070

DOI: https://doi.org/10.18524/2308-3255.2019.25.195589

\section{Зображальна журналістика та її жанри у висвітленні проблеми «кризи біженців» англійськими виданнями (на прикладі видання «The Guardian»)}

\section{Алла Коваленко,}

канд. філол. наук, доцент кафедри періодичної преси та медіаредагування Одеського національного університету імені I. І. Мечникова e-mail:longms@rambler.ru

\section{Наталя Алексєєва,}

аспірант кафедри граматики англійської мови

Одеського національного університету імені I. I. Мечникова, e-mail: natalie.m.alekseeva@gmail.com

У ході написання розвідки й дослідження соціальної проблеми «кризи біженців» у європейських країнах здійснювався моніторинг журналістських матеріалів газети «The Guardian». Було виявлено й проаналізовано вплив візуальних компонентів матеріалів на сприйняття читацької аудиторії у висвітленні вищезазначеного питання. Окреслено специфіку світлини, фотомонтажу, фотоколажу, карикатури, малюнка, фоторепортажу, фотогалереї, фотоесе та інфографіки у виданні. Встановлено, що в окремих випадках зображальна журналістика демонструє високу впливовість і ефективність у вирішенні питання гуманітарної кризи, хоча межа між ефективністю 
та маніпулюванням доволі несЗображальний компонент у виданні завдяки окремо створеному інформаційному банкінгу «The Guardian Datablog» використовується і як окрема одиниця інформації, і як допоміжний елемент гіпертексту в мультимедіа, і як окремий спосіб нарації, і як засіб емоційного та естетичного впливу, а також соціального інжінірінгу, формування окремих ком’юніті. Крім того, такі хостинги дозволяють представникам різних професій і соціальних груп використовувати зображальний компонент у своїх матеріалах і розвивають громадянську журналістику.

Ключові слова: міграційна криза, біженці, жанр, зображальна журналістика, вплив.

\section{References:}

1. Akchurin, D. G. (2012). Osnovy sovremennoy fotozhurnalistiki : uchebnoe posobie [Modern Photojournalism Basics : Schoolbook]. Kazan. [In Russian].

2. Balaklitsky, M. A. (2019). Zobrazhal'na zhurnalistika : navchalnometodychniy posibnyk dlya studentiv zi special'nosti «zhurnalistika» [Visual Journalism : Educational-Methodical Facilitator for Students in The Specialty of Journalism]. Kharkiv. [In Ukrainian].

3. Barthes, R. (2003). Sistema mody. Stat'i po semiotike kultury [The Fashion System. Culture semiotics articles]. Moscow [In Russian].

4. Benjamin, V. (2013). Kratkaya istoriya fotografii [esse] [Brief History of Photography]. Moscow [In Russian].

5. Berezin, V. M. (2019). Fotozhurnalistika : uchebnik dlya akadem. bakalavriata [Photojournalism : Textbook for Bachelor Academy] Moscow [In Russian].

6. Baudrillard J., Fotografiya, ili Pis'mo Sveta [Photography, or The Writing of Light] Translated by Arsen Melikyan Access mode. URL: http://cs5.a5.ru/med ia/6e/20/49/6e204984c118847b3a389be9cefcf83c.pdf. (accessed: 6.05.2019) [In Russian].

7. Weishenberg, S. (2011). Zhurnalistika ta Media : dovidnyk [Journalism and Media : Directory]. Kyiv [In Ukrainian].

8. Gorevalov, S., Zikun, N. (2014). Zhanry fotozhurnalisiky v Umovah Posulennya Tendenciyi Visualizatziyi ZMI [Photojournalism Genres in 
Circumstances of Media Visualization Tendencies Escalation]. Scientific notes of the Journalism Institute. Ternopil. Vol. 56. pp. 257-261 [In Ukrainian].

9. Karavayeva, A. (1981). Fotopublicistika Periodu Velikoyi Vutciznyanoyi Viyny 1941-1945 rr. [Photojournalism of the Great Patriotic War 1941-1945 years]. Moscow [In Russian].

10. BBC Editorial Guidelines, Access mode URL: http://www.bbc.co.uk/ ukrainian/indepth/story/2005/11/051125_bbc_ukraine.shtml (accessed: 6.05.2019) [In English].

11. Tonkih, I. Internet-jurnalistika. Janri $\mathrm{v}$ interneti : navchalniy posibnyk. URL: $\quad$ https://mail.rambler.ru/m/folder/INBOX/12486.3/download/id/Tonkikh Internet-Journ (accessed: 6.05.2019) [In Ukrainian].

12. Flusser, V. Za filosofiyu fotografii (2008). [Towards a philosophy of photography]. Saint Petersburg. 146 p. [In Russian].

13. Cherkova, A. I. (2014). Taimlain kak specificheskiy vid jurnalistskogo tvorchestva $\mathrm{v}$ Internetie : teoriya i praktika [Timeline as a specific type of journalist's creation on the Internet : theory and practice]. Znak. Problemnoe pole mediaobrazovania. Vol. 2 (14). pp. 112-124 [In Russian].

14. Chernyakov, B. I. (1998). Zobrazhalna jurnalistika v drukovanih zasobah masovoi informacii vid viniknennya do seredini XIX stolittya : avtoreferat dusertacii na zdobuttya naukovogo stupenya doktora filologichnih nauk : specialnist' 10.01.08. [Pictorial Journalism in Print Media from the Emergence to the Mid-Nineteenth Century : abstract of the dissertation for the Philology Ph. D.]. Kyiv. 37 p. [In Ukrainian].

15. Chernyakov, B. I. (1998). Ilyustrovana knizhkova periodika u procesi stanovlennya rann'oi zobrazhal'noi jurnalistiki [Illustrated book periodicals in the process of incipience of early illustrated journalism]. Kyiv. 155 p. [In Ukrainian].

16. Chernyakov, B. I. (1996). Fotografia v izobrazitel'noi jurnalistike : henesis technicheskih I tvorcheskih vozmozhnostei [Photography in Illustrated Journalism : The Genesis of Technical and Creative Opportunities]. Kyiv. 119 p. [In Russian].

17. Shenderovs'kiy, K. S. (2012). Mediakomunikacii ta social'ni problemi : zbirnik navchal'no-metodichnih materialiv I naukovih stattei $\mathrm{v}$ trioh chastinah, Chastina persha [Media Communication \& Social problems : Compilation of Tutorials and Articles in three parts, Part one]. Kyiv. 288 p. [In Ukrainian]. 
18. Shtompka, P. (2007). Vvedenie v vizual'nuyu sociologiyu [Introduction to visual psychology]. INTER. Vol. 1. №. 4. pp. 6-12 [In Russian].

19. Barr, C. A decade of the Datablog : 'There's a human story behind every data point'. URL: https://www.theguardian.com/membership/datablog/2019/ mar/23/a-decade-of-the-datablog-theres-a-human-story-behind-every-data-point (accessed: 18.11.2019) [In English].

20. Bell, S. Steve Bell on David Cameron's response to the refugee crisis cartoon. URL: https://www.theguardian.com /commentisfree/picture/2015/sep/03/ steve-bell-david-cameron-refugee-crisis-cartoon (accessed: 11.16.2019) [In English].

21. Brüggemann, J. Distant shores : tourists and refugees on Kos in pictures. URL: https://www.theguardian.com/world/gallery/2015/sep/04/distantshores-tourists-and-refugees-on-kos-in-pictures (accessed: 15.10.2019) [In English].

22. Drabble, E. \#3000chairs : the empty chairs of Syrian child refugees — in pictures. URL: https://www.theguardian.com/childrens-books-site/gallery/2016/ may/03/3000chairs-empty-chairs-of-syrian-refugees (accessed: 20.10.2019) [In English].

23. Editorial Guidelines. Guardian News \& Media Editorial. URL: https:// www.theguardian.com/info/2015/aug/05/the-guardians-editorial-code (accessed: 18.11.2019) [In English].

24. Jack, I. Can images change history? URL: https://www.theguardian.com/ commentisfree/2015/sep/04/images-aylan-kurdi-syria (accessed: 11.06.2019) [In English].

25. Joffe, J. Trump has bared his fangs to Merkel. He will do untold damage to Europe. URL: https://www.theguardian.com/commentisfree/2017/jan/17/trumpmerkel-europe-brexit-putin-nato (accessed: 23.10.2019) [In English].

26. Kim, J. J. World Press Photo 2016 winners — in pictures. URL: https:// www.theguardian.com/media/gallery/2016/feb/18/world-press-photo-2016winners-in-pictures (accessed: 10.10.2019) [In English].

27. Nardelli, A. How does UK refugee commitment compare with other countries? URL : https://www.theguardian.com/news/datablog/2015/ sep/08/uk-refugee-plan-comparison-european-countries (accessed: 23.10.2019) [In English]. 
28. Powell, J. The 20 photographs of the week. URL: https://www.theguardian. com/artanddesign/gallery/2015/oct/24/the-20-photographs-of-the-week (accessed: 16.10.2019) [In English].

29. Rees-Bloor, N. Phoho highlights of the day : abseiling, protests and dog racing. URL: https://www.theguardian.com /world/gallery/2015/sep/07/photohighlights-of-the-day-abseiling-protests-dog-racing-refugee-crisis

(accessed: 26.11.2019) [In English].

30. Smith, D. M. Keleti to Austria on foot : the journey that transformed Europe's refugee crisis — in pictures. URL: https://www.theguardian.com/world/ ng-interactive/2015/sep/10/keleti-to-austria-on-foot-the-journey-that-transformedeuropes-refugee-crisis-in-pictures (accessed: 28.11.2019) [In English].

31. Smith, H. Alan Kurdi : friends and family fill in gaps behind harrowing images. URL: https://www.theguardian.com/world/2015/sep/03/refugee-crisisfriends-and-family-fill-in-gaps-behind-harrowing-images (accessed: 24.10.2019) [In English].

32. Smith, H. Shocking images of drowned Syrian boy show tragic plight of refugees. URL: https://www.theguardian.com/world/2015/sep/02/shocking-imageof-drowned-syrian-boy-shows-tragic-plight-of-refugees (accessed: 5.11.2019) [In English].

33. Sontag, S. (1977). On photography. New York. 207 p. [In English].

34. Stevens, T. \#LightTheDark : readers share their photos from around Australia. URL: https://www.theguardian.com/australia news/gallery/2015/ sep/08/lightthedark-readers-share-their-photos-from-around-australia (accessed: 10.09.2019) [In English].

35. Taylor, D. Trump doesn't let facts get in the way of immigration scare stories. He's not alone. URL: https://www.theguardian.com/commentisfree/2017/ jan/16/donald-trump-immigration-fake-news-us-president-elect-asylum-seekerseurope (accessed: 23.10.2019) [In English].

36. Valle, J. M. (1978). Imágenes-tatuaje. Mensaje y Medios. 47 p. [In Spanish] 